\title{
Clofazimine as a Treatment for Multidrug-Resistant Tuberculosis: A Review
}

\author{
Rhea Veda Nugraha ${ }^{1}\left(\mathbb{D}\right.$, Vycke Yunivita $^{2}\left(\mathbb{D}\right.$, Prayudi Santoso ${ }^{3}$, Rob E. Aarnoutse ${ }^{4}$ and Rovina Ruslami ${ }^{2, *}$ \\ 1 Department of Biomedical Sciences, Faculty of Medicine, Universitas Padjadjaran, Bandung 40161, Indonesia; \\ rhea19002@mail.unpad.ac.id \\ 2 Division of Pharmacology and Therapy, Department of Biomedical Sciences, Faculty of Medicine, \\ Universitas Padjadjaran, Bandung 40161, Indonesia; v.yunivita@unpad.ac.id \\ 3 Department of Internal Medicine, Faculty of Medicine, Universitas Padjadjaran—Hasan Sadikin Hospital, \\ Bandung 40161, Indonesia; prayudi@unpad.ac.id \\ 4 Department of Pharmacy, Radboud University Medical Center, Radboud Institute for Health Sciences, \\ 6255HB Nijmegen, The Netherlands; Rob.Aarnoutse@radboudumc.nl \\ * Correspondence: n.ruslami@gmail.com
}

Citation: Nugraha, R.V.; Yunivita, V.; Santoso, P.; Aarnoutse, R.E.; Ruslami, R. Clofazimine as a Treatment for Multidrug-Resistant Tuberculosis: A Review. Sci. Pharm. 2021, 89, 19. https://doi.org/10.3390/ scipharm 89020019

Academic Editor: Roman B. Lesyk

Received: 22 February 2021

Accepted: 11 May 2021

Published: 18 May 2021

Publisher's Note: MDPI stays neutral with regard to jurisdictional claims in published maps and institutional affiliations.

Copyright: (c) 2021 by the authors. Licensee MDPI, Basel, Switzerland. This article is an open access article distributed under the terms and conditions of the Creative Commons Attribution (CC BY) license (https:// creativecommons.org/licenses/by/ $4.0 /)$.

\begin{abstract}
Multidrug-resistant tuberculosis (MDR-TB) is an infectious disease caused by Mycobacterium tuberculosis which is resistant to at least isoniazid and rifampicin. This disease is a worldwide threat and complicates the control of tuberculosis (TB). Long treatment duration, a combination of several drugs, and the adverse effects of these drugs are the factors that play a role in the poor outcomes of MDR-TB patients. There have been many studies with repurposed drugs to improve MDR-TB outcomes, including clofazimine. Clofazimine recently moved from group 5 to group B of drugs that are used to treat MDR-TB. This drug belongs to the riminophenazine class, which has lipophilic characteristics and was previously discovered to treat TB and approved for leprosy. This review discusses the role of clofazimine as a treatment component in patients with MDR-TB, and the drug's properties. In addition, we discuss the efficacy, safety, and tolerability of clofazimine for treating MDR-TB. This study concludes that the clofazimine-containing regimen has better efficacy compared with the standard one and is also well-tolerated. Clofazimine has the potential to shorten the duration of MDR-TB treatment.
\end{abstract}

Keywords: clofazimine; MDR-TB; efficacy; safety; tolerability

\section{Introduction}

Tuberculosis (TB) that is resistant to at least isoniazid and rifampicin is called multidrugresistant tuberculosis (MDR-TB). MDR-TB has caused a complexity of TB treatment, represents an extreme risk worldwide, and needs new strategies for its treatment [1-3]. The latest report from the World Health Organization (WHO) stated that there were about 465,000 people worldwide with rifampicin-resistant tuberculosis (RR-TB) in 2019, and $78 \%$ of these have MDR-TB [4]. Treatment of MDR-TB takes more time and needs a more complex combination of drugs than drug-susceptible TB. MDR-TB treatment regimens are recommended by the $\mathrm{WHO}$ and classified based on the duration as short and long treatment regimens. A combination of several drugs needs to be used to treat MDR-TB, such as fluoroquinolones, bedaquiline, linezolid, clofazimine, cycloserine or terizidone, ethambutol, delamanid, pyrazinamide, imipenem-cilastatin or meropenem, amikacin, streptomycin, ethionamide or prothionamide, and para-aminosalicylic acid [2]. The WHO previously regarded clofazimine as a group 5 medicine, which is an agent with unclear efficacy against MDR-TB [5]. It was later moved to group B, as an agent that is recommended as a second-choice medicine to treat MDR-TB [2]. We aimed to review the role of clofazimine in MDR-TB, discuss this drug and its properties, and provide new information about this drug's clinical benefits in MDR-TB treatment. 


\section{Multidrug-Resistant Tuberculosis}

\subsection{Epidemiology of MDR-TB}

In 2019, the WHO stated that about 10 million people have TB worldwide. This number has decreased by $9 \%$ since 2015 (from 142 to 130 new cases per 100,000 people). TB is the leading infectious disease killer worldwide; 1.4 million people die each year from this disease. The Global Tuberculosis Report 2020 informed that drug-resistant tuberculosis (DR-TB) continues to be a threat to public health. The number of RR-TB cases was 465,000 , and $78 \%$ of all RR-TB cases worldwide were MDR-TB in 2019. India had the highest number of MDR-TB cases (27\%), followed by China (14\%) and the Russian Federation (8\%). Globally, $3.3 \%$ of new TB cases and $17.7 \%$ of previously treated TB are RR/MDR-TB. The number of individuals treated with RR/MDR-TB continues to increase every year [4].

\subsection{Treatment of $M D R-T B$}

Currently, MDR-TB can be treated with two regimens. The WHO recommended these regimens and classified them, based on the duration of treatment, as a short and a long treatment regimen. For the short regimen, 9-11 months of treatment are suggested, and a long regimen lasts for 18-20 months (15 months after culture conversion, at least) [1,6].

There are some groups of drugs that are used to treat MDR-TB: group A, B, C, and other medicines. Group A involves drugs that are considered highly effective and are strongly recommended for the treatment of MDR-TB, such as levofloxacin or moxifloxacin, bedaquiline, and linezolid. Besides these, clofazimine and cycloserine or terizidone are recommended as second line agents and included in group B. Group $C$ can be used when group A and B drugs cannot be used as a regimen. The drugs that belong to Group C are ethambutol, delamanid, pyrazinamide, imipenem-cilastatin or meropenem, amikacin, streptomycin, ethionamide or prothionamide, para-aminosalicylic acid. Other medicines used for MDR-TB are kanamycin, capreomycin, and amoxicillin-clavulanic acid [2].

\section{Clofazimine}

\subsection{Introduction to Clofazimine}

Barry et al. [7] first described clofazimine in 1957. Clofazimine is a lipophilic riminophenazine that was initially developed to treat $\mathrm{TB}$, but it was not effective enough to treat TB infection in primates and humans [8]. Investigations into this drug in the animal experiment showed mixed results. Clofazimine was as effective in rats and hamsters as it was in mice. In guinea pigs, rabbits, and monkeys, much higher doses were needed to reverse established disease. It later became known that the effectiveness in mice, hamsters, and rats is favorable, due to its good absorption by the oral route. However, in guinea-pigs and monkeys, the drugs' poor absorption leads to its failure [7,9]. Successful results gained from animal experiments led to the study of the drug's effect in chronic pulmonary TB in man, and the results were disappointing $[9,10]$. However, the poor outcomes of clofazimine coincided with the discovery of pyrazinamide (in 1952) and ethambutol (in 1961), which showed better efficacy and fewer adverse effects. Rifampicin was discovered in 1968, and it contributed to shortening the duration of treatment. These three agents, concurrently with streptomycin and isoniazid, found in advance of clofazimine in 1943 and 1945, respectively, overshadowed clofazimine [8]. Later, in the 1960s, clofazimine was prescribed to treat leprosy, combined with rifampicin and dapsone [8,11].

The interest in the clofazimine-containing regimen (CCR) for MDR-TB treatment rose after a study conducted by Van Deun et al. [12]. Their observational study evaluated the effectiveness of standardized regimens for untreated MDR-TB with second-line drugs. The results showed that clofazimine-containing regimens included high-dose fluoroquinolones (gatifloxacin and ofloxacin) and other drugs (kanamycin, ethambutol, isoniazid, pyrazinamide, and prothionamide) were effective to treat MDR-TB. These drugs were also ready to shorten therapy length in MDR cases [12,13]. In turn, clofazimine, formerly placed by the WHO in group 5, amongst other drugs with indistinct efficacy for MDR-TB, was moved to group B drugs, which are recommended in combination in an MDR-TB regimen [13,14]. 


\subsection{Chemical Properties of Clofazimine}

Clofazimine is one of the lipophilic riminophenazines synthesized by Barry et al. [7] in 1957. This riminophenazine was a structural modification from Barry's previous discovery of anilinoaposafranine [10]. The main structure of clofazimine is the phenazine nucleus. This nucleus is accompanied by phenyl substituents and an R-imino group (Figure 1). The R-imino group has critical structural features for its activity against mycobacteria [15].

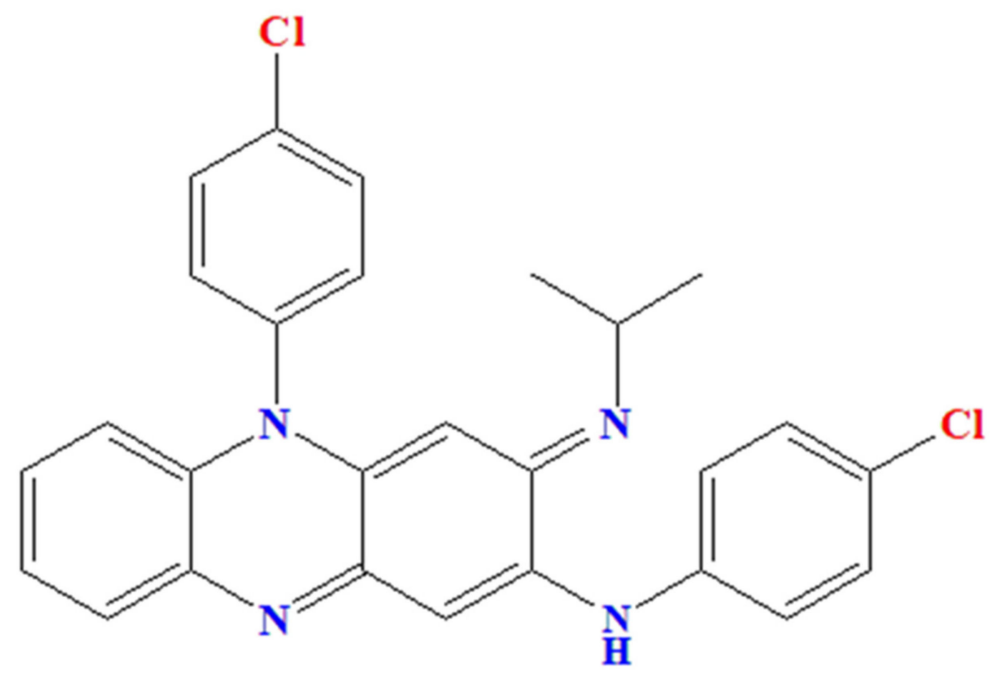

Figure 1. Molecular structure of clofazimine. (The figure was modified from PubChem) [16].

\subsection{Mechanism of Action of Clofazimine}

Clofazimine's mechanism of action as an anti-mycobacterial drug is still not entirely understood. There are some main effects of clofazimine on mycobacteria, which have already been elucidated [15,17-19]. Bopape et al. [17] carried out an in vitro study on the anti-mycobacterial activity of clofazimine. This study showed that clofazimine increases the effect of bacterial phospholipase A2 and release lysophospholipids. This enzyme is toxic to mycobacteria; hence, this drug has an anti-mycobacterial effect. An investigation in 2011 showed clofazimine's mechanism of action in macrophages. The study showed that clofazimine induces apoptosis through the caspase 3 pathways in the human macrophage's cell line using the human monocyte-derived macrophages cell line and the human monocytic leukemia cell line THP-1. This action included the fragmentation of DNA during the apoptosis process [18]. Another study by Lechartier et al. [19] reported the clofazimine's mechanism of action. This mechanism is suggested to occur by competing with menaquinone, the sole quinone cofactor in mycobacteria, for the electron carried by the flavin adenine dinucleotide (FAD) of reduced NDH-2. Some studies explained that clofazimine affects the outer membrane of mycobacteria. This effect occurred through the inhibition of the mycobacterial respiratory chain and its ion transporters by acting as artificial electron acceptors. Thus, clofazimine was oxidized by the respiratory system instead of NADH. This mechanism causes a reduction in ATP amounts. The redox potential of clofazimine caused the production of reactive oxygen species $[15,17]$. Based on these data, clofazimine's main effects as an anti-mycobacterial need further investigation to describe clofazimine's mechanism of action more specifically $[15,17-19]$.

Diacon et al. [20] conducted an in vitro study to evaluate the 14-day bactericidal activity of clofazimine and pyrazinamide in monotherapy and combination with pretomanid and bedaquiline in 2015. The results showed that bedaquiline, pretomanid, and pyrazinamide have the highest bactericidal activity, and clofazimine did not show any action within 14 days. In an in vitro and in vivo study, Ammerman et al. [21] assessed the early bactericidal activity (EBA) of clofazimine against $M$. tuberculosis. The in vitro study showed that clofazimine did not exert any activity during the first 2-4 days of exposure, but, after one week, revealed concentration-dependent anti-mycobacterial activity, e.g., bacteriostatic 
activity, at a concentration at or below the $0.25 \mathrm{mg} / \mathrm{L}$ minimum inhibitory concentration (MIC), and bactericidal activity at a concentration above the MIC. The mean $\mathrm{EBA}_{0-2}$ value for clofazimine at any concentration was almost zero, and $\mathrm{EBA}_{7-14}$ increased with each concentration. In mice receiving clofazimine (in vivo study), the lungs' bacterial load continued to grow during the first seven days of treatment. Later, after ten days, bacterial loads in the lungs were significantly lower than those in the control group. Thus, clofazimine's anti-TB activity was delayed because there was no bactericidal activity in the first week in any concentration, either in vitro or in vivo, and there was a concentration-dependent bactericidal activity in the second week of clofazimine.

Another review explained another mechanism of clofazimine, aside from anti-mycobacterial activity. Clofazimine acts as a pro-oxidative and anti-inflammatory agent in erythema nodosum leprosum (ENL) in leprosy and other inflammatory diseases, besides its effects as an anti-mycobacterial drug [10].

\subsection{Synergism Activity of Clofazimine}

MDR-TB treatment requires a regimen containing a combination of anti-mycobacterial drugs such as levofloxacin or moxifloxacin, bedaquiline, linezolid, clofazimine, cycloserine or terizidone, ethambutol, delamanid, pyrazinamide, imipenem-cilastatin or meropenem, amikacin or streptomycin, ethionamide or prothionamide, and para-aminosalicylic acid for a minimum of 9 months [14]. Therefore, studies on the synergism of drugs need to be evaluated. Several studies showed the synergism of clofazimine with other antimycobacterial medicines in in vitro, in vivo, and a clinical setting [22-24].

An earlier study in 2015 compared the efficacy of three combinations, including clofazimine/pretomanid/levofloxacin, clofazimine/pretomanid/moxifloxacin, and clofazimine/pretomanid/UB8902, against MDR- and drug-sensitive $M$. tuberculosis strains. UB8902 was a novel fluoroquinolone, which is a ciprofloxacin derivative. This study showed that the fractional inhibitory concentration index (FICIs) of all combinations ranged from 1.2 to 2.3 , indicating an additive activity against all the isolates. The results of the FICI analysis were assessed according to the chequerboard method. FICI $<0.75,0.75-4$, and $>4$ was interpreted as synergistic, additive/indifferent, and antagonistic activity, respectively. Thus, these three combinations of clofazimine showed similar effects [23].

In another in vitro study held in China done by Li et al. [22] on synergistic activities of clofazimine with moxifloxacin or capreomycin against $M$. tuberculosis, they indicated that the combination of clofazimine and moxifloxacin displayed more synergism than capreomycin with clofazimine. These results - as described by comparing the minimum FICs between the clofazimine/capreomycin, and clofazimine/moxifloxacin combination-demonstrate synergism against 21 and 29 strains, respectively. Additionally, the comparison between maximum FICs between these combinations revealed 12 and 9 strains that showed antagonism. Hence, clofazimine with moxifloxacin showed better synergism than clofazimine with capreomycin and may be a promising drug combination for MDR-TB treatment.

Maartens et al. [24] conducted a secondary analysis of an observational study of drugs interactions to assess the interaction between clofazimine and bedaquiline. This study showed that there were no interaction pharmacokinetics between clofazimine and bedaquiline. There were no significant effects on the bioavailability of bedaquiline when combined with clofazimine. Clofazimine only impacted bedaquiline and not M2 (the $N$-monodesmethyl metabolite of bedaquiline) using a population pharmacokinetic model (not statistically significant). Thus, it is safe to combine these drugs to treat MDR-TB.

Taken together, we can conclude that the combination of clofazimine and other anti-TB drugs, such as moxifloxacin, levofloxacin, pretomanid, a novel quinolone (UB-8902), and bedaquiline, shows additive and synergistic activity against $M$. tuberculosis strains [22-24]. Bedaquiline combinations with clofazimine had no significant pharmacokinetic interaction in the clinical setting. These combinations need to be further evaluated, especially their interaction in the clinical setting [24]. 


\subsection{Pharmacokinetics of Clofazimine}

According to the WHO's MDR-TB guideline, clofazimine is administered in a $100 \mathrm{mg}$ dose once daily to treat MDR-TB. This dose is fixed regardless of the weight of the patient [2]. Because of its lipophilicity, clofazimine is administered as a microcrystalline suspension in an oil-wax base to improve absorption [5]. The absorption of clofazimine in microcrystalline suspension in an oil-wax base was 70\%; if in coarse crystal in a capsule, it is about 20\% [25]. In humans, the absorption of orally administered clofazimine varies at around $45-62 \%$. Its absorption is associated with whether the drug is taken with or without food [5]. A single oral administration of $200 \mathrm{mg}$ clofazimine tablet with fats and protein generates the peak plasma drug concentration $\left(C_{\max }\right)$ around $0.41 \mathrm{mg} / \mathrm{L}$, with a $t_{\max }$ of approximately $8 \mathrm{~h}$. When the drug is taken without food, the $C_{\max }$ was $30 \%$ less, with the $t_{\max }$ of $12 \mathrm{~h}[5,11]$. Peak serum levels of $4 \mathrm{mg} / \mathrm{L}$ were found after administration of $600 \mathrm{mg}$ of this drug. The peak serum levels of $600 \mathrm{mg}$ clofazimine were much higher than in $200 \mathrm{mg}$ clofazimine. This high peak serum of $600 \mathrm{mg}$ clofazimine may guide the use of clofazimine in a higher dose to treat MDR-TB to increase its serum concentrations [5]. A high-fat meal was the main factor in clofazimine's bioavailability. Antacid and orange juice could decrease the mean bioavailability of clofazimine. Therefore, we can conclude that clofazimine has better absorption if taken with a high-fat and -protein meal. Its bioavailability will be lower if taken with an antacid and orange juice [26].

In plasma, clofazimine is present both in its free form and bound to proteins as transporter carriers [10]. Because of clofazimine's lipophilic characteristic, this drug is distributed to fatty tissue, mainly and inside macrophages throughout the body [25]. Clofazimine accumulates inside acidic organelles by $\mathrm{pH}$-dependent ion-trapping and druginduced, autophagosome-like, drug-membrane aggregates. This accumulation initially occurs in adipose tissue, then has a massive distribution to reticuloendothelial cells [27]. During its long-term tissue accumulation, clofazimine experiences xenobiotic sequestration, resulting in the formation of intracellular crystal-like drug inclusions (CLDIs) in the cytoplasm of tissue macrophages [8]. Clofazimine also causes cutaneous pigmentation, which could disappear in 6-12 months [5]. Even though clofazimine is lipophilic, the drug cannot penetrate and accumulate in caseous granuloma formed by epithelioid macrophages surrounding a cellular necrotic region [28,29]. Clofazimine accumulated more in the cellular peripheral zone than in the lesion's necrotic core [29]. This lack of clofazimine penetration into the necrotic foci leads to its poor accumulation and may contribute to its failure to act on the non-replicating bacilli in the necrotic foci or granuloma core of $\mathrm{C} 3 \mathrm{HeB} / \mathrm{FeJ}$ mice $[5,8,29]$.

There is limited information available about the metabolism of clofazimine. Studies reported that clofazimine is metabolized into three compounds or metabolites. These metabolites are formed in the liver through the process of hydrolytic dehalogenation (metabolite I), hydrolytic deamination with glucuronidation (metabolite II), and hydration with glucuronidation (metabolite III). After the administration of clofazimine at $300 \mathrm{mg} /$ day, less than $1 \%$ of metabolite I $(0.2 \%)$, II $(0.25 \%)$, and III $(0.2 \%)$ are excreted in the urine within $24 \mathrm{~h}$. Metabolites represent about $1 \%$ of the drug in urine and about $50 \%$ in feces after $24 \mathrm{~h}$ of administration [10]. There are no data on the pharmacological activity of these metabolites [25].

A study conducted by te Brake et al. [30] indicated that clofazimine is a potent inhibitor of P-glycoprotein, Breast Cancer Resistance Protein (BCRP), and Multidrug Resistanceassociated Protein 1 (MRP1) transporters. These inhibitions of membrane transporters may lead to drug-drug interactions (DDIs). Thus, the co-administration of clofazimine with substrates for these transporters may cause DDIs, e.g., clofazimine may decrease phenytoin, a substrate of P-gp, concentration, due to their interaction in the transporters.

Clofazimine tends to remain for a long time in human tissues and has a slow elimination. The elimination half-life $\left(t_{1 / 2}\right)$ of clofazimine is still unclear. A study conducted in 1974 showed that clofazimine has a half-life of about $10.6 \pm 4$ days, estimated from the first dose taken. With this prolonged half-life, the steady-state of clofazimine will be 
achieved in approximately 30 days [25]. Some previous clinical studies used 200 to $300 \mathrm{mg}$ of clofazimine in MDR/XDR-TB patients, which was caused by the long time clofazimine took to achieve steady-state [31-33]. The use of a higher dose of clofazimine in some clinical studies is a 'loading dose', similar to other drugs with a long elimination half-life, e.g., digoxin.

\subsection{Effectivity of Clofazimine for Treating MDR-TB in the Mouse Model Tuberculosis}

Some studies reported that clofazimine has good activity against MDR-TB in animal model studies [34,35]. Grosset et al. [34] performed a study to assess clofazimine's TB activity in a MDR-TB mouse model. The results showed that there was a decline in bacterial lung load after 2 months of treatment. The lungs' bacillary load was reduced from $9.74 \log _{10}$ at baseline to 3.61 and 4.68 in mice treated with clofazimine and second-line TB regimen (moxifloxacin, ethambutol, pyrazinamide, and amikacin) after 2 months of treatment. This study also reported that mice treated with clofazimine were culture-negative after 5 months of treatment; meanwhile, mice treated without clofazimine still were culture-positive after 9 months. Mice that received clofazimine had a relapse rate of only 7\% for 8-9 months. This study showed that clofazimine's contribution to a 9-months second-line regimen for TB's activity has a positive response. Clofazimine's addition to the regimen increased the efficacy of the second-line regimen of TB.

Another study was conducted on the impact of clofazimine in the TB mouse model to assess its bactericidal and sterilizing activity. The addition of clofazimine to the regimen showed a declined lung bacterial load and increased bactericidal activity. This study also indicated that the clofazimine regimen decreased the duration of treatment necessary to achieve a relapse-free cure in up to 1-2 months, with a dose of $>6.25 \mathrm{mg} / \mathrm{kg}$. The addition of clofazimine to the regimen for TB could shorten the treatment duration [35].

However, Prideaux et al. [29] stated that a lack of clofazimine penetration into the necrotic core leads to clofazimine's limited activity in the $\mathrm{C} 3 \mathrm{HeB} / \mathrm{FeJ}$ mouse strain, which causes the human-like hypoxic granulomatous lung lesions upon TB infection [36]. According to this study, clofazimine showed pronounced aggregation in cellular layers in relation to caseum in human resected lung tissue. Additionally, Irwin et al. [37] found minimal clofazimine monotherapy activity in $\mathrm{C} 3 \mathrm{HeB} / \mathrm{FeJ}$ mice. This hypoxic condition in $\mathrm{C} 3 \mathrm{HeB} / \mathrm{FeJ}$ mice may increase the chances of the bacteria becoming resistant, caused by the subtherapeutic exposure levels, poor drug penetration or high bacterial mutation frequency within the hypoxic lung lesions. This condition may result in an ineffective clofazimine monotherapy in $M$. tuberculosis-infected C3HeB/FeJ mice [37-40]. There is no data available to date that describe the combination of clofazimine with standard TB treatment in Kramnik mice. Still, Grosset et al. and Ammerman et al. used standard regimen therapy for MDR-TB- and TB-susceptible models with or without clofazimine [29,34,41]. This difference explained the conflicting results of those studies, because the distinct regimen therapy and the pathogenesis in the animal model led to a different response to the clofazimine treatment [29,34,37,41,42]. Nevertheless, the Kramnik mouse model warrants further evaluation as a more stringent animal model that mimics the pathology of human lung granuloma [38-40].

Altogether, we can conclude that the addition of clofazimine to the regimen can reduce the lung bacterial load and relapse rate in mice. Then, this drug might have the potential to shorten the duration of MDR-TB treatment, but this still needs to be evaluated, especially in a clinical setting [34,35].

\subsection{Effectivity of Clofazimine for Treating $M D R-T B$}

Several studies indicated that the clofazimine-containing regimen (CCR) has a better treatment outcome against MDR-TB in observational and comparative studies (Table 1). The treatment outcomes were measured, with a successful treatment rate, time to culture conversion, and a cavity closure rate [12,33,41-49]. 
Successful treatment is defined as cured and completed treatment by Laserson et al. Cured is defined as patients who completed treatment according to the program protocol with five or more negative cultures for the final 12 months of treatment. Completed treatment was described as a patient who completed treatment according to the program protocol with documented bacteriological conversion status persisting up to the end of treatment, or did not meet the criteria of cure [50].

Van Deun et al. [12] in 2010 conducted a cohort study to assess the effectiveness of second-line drugs (SLDs) for untreated MDR-TB. This study compared six regimens with all of them, including clofazimine. Clofazimine was in regimens 1-4 only for the intensive phase and regimens 5-6 for both the intensive and continuation phases of treatment. The results indicated that the overall regimen had a cure rate above $55 \%$ and regimen $5-6$ showed a statistically significant higher cure rate than regimen $1-4(84.2 \%$ and $82.5 \%$, respectively). It was concluded that CCR, both in the intensive and continuation phase, showed promising treatment outcomes compared with administration in the intensive phase only, and clofazimine was one of the most effective antibiotics in combination therapy.

Another investigation into clofazimine for MDR-TB was performed in 2012. This retrospective-observational study evaluated the addition of clofazimine into an individualized regimen for MDR-TB. This study reported that 15 out of $39(38 \%)$ patients achieved a successful treatment, and 22 out of 39 patients achieved negative culture conversion, with a median time of 12 weeks (range $2-48$ weeks). These outcomes suggest that clofazimine contributed to these favorable treatment results [41].

Dey et al. [33] carried out a systematic review and meta-analysis of CCRs' outcomes for the treatment of DR-TB. They reported that $16.5-87.8 \%$ of 3472 patients (from 11 studies) had a successful treatment, both cured and completed treatment, and the overall pooled proportion of treatment success was $61.96 \%$. This showed that the treatment outcome of the CCRs has better efficacy compared with the standard one.

A prospective observational study was done by Aung, et al. [42] in Bangladesh on MDR-TB patients, who received a standardized regimen that included clofazimine for a minimum of 9 months. The results demonstrated that 435 of $515(84.5 \%)$ patients had successful treatment. Only 50\% of them completed the treatment in 9 months. However, $95 \%$ of patients completed the therapy within 1 year. This study also showed that $93 \%$ of patients experienced culture conversion at month 2 of treatment, and $84.4 \%$ had a bacteriologically favorable outcome. Besides that, there were 358 of $415(82.3 \%)$ patients who did not relapse for 24 months, and $93.1 \%$ for $\geq 12$ months, after treatment completion. 
Table 1. Effectivity of Clofazimine for Treating MDR-TB and XDR-TB in Observational and Comparative Studies.

\begin{tabular}{|c|c|c|c|c|c|c|}
\hline \multirow{2}{*}{ Study } & \multirow{2}{*}{ Type of Study } & \multirow{2}{*}{ Dose and Duration of Clofazimine } & \multirow{2}{*}{$\begin{array}{l}\text { Other Drugs included } \\
\text { in the Regimen }\end{array}$} & \multicolumn{3}{|c|}{ Outcome } \\
\hline & & & & Time to Culture Conversion & Cavity Closure & Treatment Success Rate \\
\hline \multicolumn{7}{|c|}{ MDR-TB } \\
\hline $\begin{array}{l}\text { Van Deun, et al. [12] } \\
2010\end{array}$ & Observational-prospective & $\begin{array}{c}\text { Dose: } 50 \mathrm{mg}(<33 \mathrm{~kg} \text { ) and } 100 \mathrm{mg} \\
\text { ( }>33 \mathrm{~kg}) \\
\text { Duration: } \\
\text { Regimen } 1: 3 \text { months } \\
\text { (intensive phase only) } \\
\text { Regimen } 2: \geq 3 \text { months } \\
\text { (intensive phase only) } \\
\text { Regimen } 3: 3-4 \text { months } \\
\text { (intensive phase only) } \\
\text { Regimen } 4: \geq 3 \text { months } \\
\text { (intensive phase only) } \\
\text { Regimen } 5: \geq 15 \text { months (intensive } \\
\text { and continuation phase) } \\
\text { Regimen } 6: \geq 9 \text { months } \\
\text { (intensive and continuation phase) }\end{array}$ & $\begin{array}{c}\text { EMB, GAT, INH, KM, OFX, } \\
\text { PTO, PZA }\end{array}$ & NA & NA & $\begin{array}{c}\text { Regimen } 1 \text { and } 2: 71 \text { of } 103(68.9 \%) \\
\text { patients were cured } \\
\text { Regimen 3: } 20 \text { of } 35(57.1 \%) \\
\text { patients were cured } \\
\text { Regimen } 4: 30 \text { of } 45(66.7 \%) \\
\text { patients were cured } \\
\text { Regimen } 5: 32 \text { of } 38(84.2 \%) \\
\text { patients were cured } \\
\text { Regimen } 6: 170 \text { of } 206(82.5 \%) \\
\text { patients were cured and } 11 \text { of } 206 \\
\text { (5.3\%) had treatment completion } \\
\text { (highly significant statistically) }\end{array}$ \\
\hline $\begin{array}{l}\text { Xu, et al. [41] } \\
2012\end{array}$ & Observational-retrospective & $\begin{array}{l}\text { Dose: } 100 \mathrm{mg} \text {, once daily } \\
\text { Duration: median } 13 \text { months } \\
\text { (range } 2-25 \text { months) }\end{array}$ & $\begin{array}{l}\text { LFX, MFX, OFX, GAT, PZA, } \\
\text { PTO, PA, INH, PAS, CLR, } \\
\text { AMK, CM, RFB, LZD, } \\
\text { AMX/CLV, RE, AT }\end{array}$ & $\begin{array}{c}\text { Median: } 12 \text { weeks } \\
\text { (range 2-48 weeks) } \\
22 \text { of } 39 \text { patients achieved } \\
\text { culture conversion to negative }\end{array}$ & NA & $\begin{array}{l}15 \text { of } 39(38 \%) \text { patients had } \\
\text { successful treatment }\end{array}$ \\
\hline $\begin{array}{l}\text { Dey, et al. [33] } \\
\quad 2013\end{array}$ & $\begin{array}{l}\text { Systematic review and } \\
\text { meta-analysis }\end{array}$ & $\begin{array}{l}\text { Dose: } 50-300 \mathrm{mg} \text {, once daily } \\
\text { (only stated in } 5 \text { studies) } \\
\text { Duration: } 2-1729 \text { days } \\
\text { (only stated in } 10 \text { studies) }\end{array}$ & $\begin{array}{c}\text { AMK/CLV, AMK, AMX, CIP, } \\
\text { CLR, CM, CYS, EMB, ETO, KM, } \\
\text { RIF, SFX, TRD }\end{array}$ & NA & NA & $\begin{array}{c}16.5-87.8 \% \text { (11 studies, } 3472 \\
\text { patients) had successful treatment } \\
\text { Overall pooled proportion of } \\
\text { treatment success was } 61.96 \%\end{array}$ \\
\hline $\begin{array}{l}\text { Aung, et al. [42] } \\
\text { 2014 }\end{array}$ & Observational-prospective & $\begin{array}{l}\text { Dose: NA } \\
\text { Duration: } 9 \text { months }\end{array}$ & $\begin{array}{c}\text { High-dose GTX, EMB, PZA, } \\
\text { KM, PTO, INH }\end{array}$ & $\begin{array}{l}\text { At month } 2 \text { of treatment, } 93 \% \\
\text { experienced culture conversion }\end{array}$ & NA & $\begin{array}{c}435 \text { of } 515(84.5 \%) \text { patients had } \\
\text { successful treatment } \\
\text { Treatment completion: } 50 \% \\
\text { completed within } 272 \text { days } \\
\text { (9 months), } 75 \% \text { within } 299 \text { days } \\
\text { (10 months), } 90 \% \text { within } 331 \text { days } \\
\text { (11 months), and } 95 \% \text { within } \\
363 \text { days ( } 1 \text { year) }\end{array}$ \\
\hline $\begin{array}{l}\text { Tang, et al. [43] } \\
2015\end{array}$ & $\begin{array}{l}\text { Multicenter, prospective, } \\
\text { randomized, controlled, and } \\
\text { open study (superiority test) }\end{array}$ & $\begin{array}{l}\text { Dose: } 100 \mathrm{mg} \text {, once daily } \\
\text { Duration: } 21 \text { months }\end{array}$ & $\begin{array}{c}\text { PTO, PZA, MFX, GAT, LFX, } \\
\text { PAS, INHa, CM, AMK, } \\
\text { EMB, CLR }\end{array}$ & $\begin{array}{c}\text { Start at } 3 \text { months after } \\
\text { treatment initiation (earlier in } \\
\text { patients who receive } \\
\text { CFZ-containing regimen } \\
\text { compared with a control group) } \\
\text { The proportion of } \\
\text { culture-positive patients } 60 \text { vs. } \\
75 \% \text { in months } 3(p=0.042)\end{array}$ & $\begin{array}{c}46 \text { of } 53 \text { patients in } \\
\text { CFZ-containing regimen vs. } 45 \text { of } \\
52 \text { patients in the control group } \\
\text { showed cavitary changed } \\
\text { Cavity closure starts at } 3 \text { months } \\
\text { after treatment initiation (earlier } \\
\text { in patients who receive } \\
\text { CFZ-containing regimen } \\
\text { compared with the control group) } \\
\text { The proportion of patients having } \\
\text { cavity } 60 \text { vs. } 75 \% \text { in months } 3 \\
(p=0.047)\end{array}$ & $\begin{array}{c}39 \text { of } 53(73.6 \%) \text { patients in } \\
\text { CFZ-containing regimen vs. } 28 \text { of } 52 \\
\text { (53.8\%) patients in control group } \\
\text { had successful treatment }(p=0.035) \\
\text { Cured: } 27 \text { of } 53(50.9 \%) \text { vs. } 20 \text { of } 52 \\
(38.5 \%) \text { patients } \\
\text { Treatment completion: } 12 \text { of } 53 \\
(22.6 \%) \text { vs. } 8 \text { of } 52(15.4 \%) \text { patients }\end{array}$ \\
\hline
\end{tabular}


Table 1. Cont.

\begin{tabular}{|c|c|c|c|c|c|c|}
\hline \multirow{2}{*}{ Study } & \multirow{2}{*}{ Type of Study } & \multirow{2}{*}{ Dose and Duration of Clofazimine } & \multirow{2}{*}{$\begin{array}{l}\text { Other Drugs included } \\
\text { in the Regimen }\end{array}$} & \multicolumn{3}{|c|}{ Outcome } \\
\hline & & & & Time to Culture Conversion & Cavity Closure & Treatment Success Rate \\
\hline $\begin{array}{l}\text { Dalcolmo, et al. [44] } \\
2017\end{array}$ & Observational-retrospective & $\begin{array}{c}\text { Dose: } 50 \mathrm{mg} \text { (' } 123+\_(\leq 45 \mathrm{mg}) \text { and } \\
100 \mathrm{mg}(>45 \mathrm{~kg}) \text {, once daily } \\
\text { Duration: } 18 \text { months }\end{array}$ & AMK, OFX, TRD, EMB, STM & NA & NA & $\begin{array}{l}880 \text { of } 1446(60.9 \%) \text { patients in } \\
\text { CFZ-containing regimen vs. } 708 \text { of } \\
1096(64.6 \%) \text { patients in } \\
\text { PZA-containing regimen group had } \\
\text { successful treatment }(p=0.054) \\
\text { Cured: } 421 \text { of } 1446(29.1 \%) \text { vs. } 384 \text { of } \\
1096(35 \%) \text { patients } \\
\text { Treatment completion: } 459 \text { of } 1446 \\
\text { (31.7\%) vs. 324 of } 1096 \\
(29.6 \%) \text { patients }\end{array}$ \\
\hline $\begin{array}{c}\text { Duan, et al. [45] } \\
2018 \\
\text { ChiCTR1800014800 }\end{array}$ & $\begin{array}{l}\text { Multicenter and } \\
\text { randomized study }\end{array}$ & $\begin{array}{l}\text { Dose: } 100 \mathrm{mg} \text {, once daily } \\
\text { Duration: } 24 \text { months }\end{array}$ & $\begin{array}{l}\text { AMK, CM, LFX, PZA, EMB, } \\
\text { PAS, PTO, AMX/CLV }\end{array}$ & $\begin{array}{l}\text { Start at } 3 \text { months after } \\
\text { treatment initiation (earlier in } \\
\text { patients who receive } \\
\text { CFZ-containing regimen } \\
\text { compared with control group) } \\
\text { Proportion of culture-positive } \\
\text { patients } 55 \text { vs. 60\% in months } 3 \\
\text { (p=0.0031) }\end{array}$ & NA & $\begin{array}{c}43 \text { of } 66(65.1 \%) \text { patients } \\
\text { CFZ-containing regimen vs. } 35 \text { of } 74 \\
(47.3 \%) \text { patients in control group } \\
(p=0.0034) \\
\text { Cured: } 36 \text { of } 66(54.5 \%) \text { vs. } 26 \text { of } 74 \\
(35.1 \%) \text { patients } \\
\text { Treatment completion: } 7 \text { of } 66 \\
(10.6 \%) \text { vs. } 9 \text { of } 74(12.2 \%) \text { patients }\end{array}$ \\
\hline $\begin{array}{l}\text { Ahmad, et al. [46] } \\
2018\end{array}$ & Meta-analysis & NA & NA & NA & NA & $\begin{array}{l}61 \% \text { had successful treatment, while } \\
8 \% \text { had failure or relapse, } \\
\text { and } 14 \% \text { died } \\
\text { Treatment success was associated } \\
\text { positively with the use of linezolid, } \\
\text { levofloxacin, carbapenem, } \\
\text { moxifloxacin, bedaquiline, } \\
\text { and clofazimine }\end{array}$ \\
\hline $\begin{array}{l}\text { Trebucq, et al. [47] } \\
\text { 2018 }\end{array}$ & Observational-prospective & $\begin{array}{l}\text { Dose: NA } \\
\text { Duration: } 9-11 \text { months }\end{array}$ & $\begin{array}{l}\text { KM, MFX, EMB, high-dose } \\
\text { INH, PZA, PTO }\end{array}$ & NA & NA & $\begin{array}{c}821 \text { of } 1006(81.6 \%) \text { patients had } \\
\text { successful treatment } \\
\text { Cured: } 728 \text { of } 1006 \text { (72.4\%) patients } \\
\text { Treatment completion: } 93 \text { of } 1006 \\
(9.2 \%) \text { patients }\end{array}$ \\
\hline $\begin{array}{l}\text { Du, et al. [48] } \\
\quad 2019 \\
\text { ChiCTR } 1800020391\end{array}$ & $\begin{array}{l}\text { Multicenter, prospective, } \\
\text { randomized, and } \\
\text { controlled study }\end{array}$ & $\begin{array}{l}\text { Dose: NA } \\
\text { Duration: } 12 \text { months }\end{array}$ & CM, CYS, LFX, PTO, PZA & $\begin{array}{l}\text { Start } 3 \text { months after treatment } \\
\text { initiation (earlier in patients } \\
\text { who receive CFZ-containing } \\
\text { short regimen compared with } \\
\text { long regimen group) } \\
68.7 \text { vs. } 55.9 \% \text { of patients } \\
\text { reached sputum-culture } \\
\text { conversion at the end of } \\
3 \text { months of treatment }(p=0.04 \text { ) } \\
\text { The proportion of } \\
\text { culture-positive patients } \\
\text { around } 20 \text { vs. } 40 \% \text { in months } 3\end{array}$ & $\begin{array}{l}\text { Cavity closure starts at } 6 \text { months } \\
\text { after treatment initiation } \\
\text { (earlier in patients who receive } \\
\text { CFZ-containing short regimen } \\
\text { compared with long } \\
\text { regimen group) } \\
\text { The proportion of patients having } \\
\text { cavity around } 80 \text { vs. } 90 \% \\
\text { in months } 6 \\
\text { Cavity closure rate in } \\
\text { CFZ-containing short regimen vs. } \\
\text { long regimen group were } 37.5 \% \\
\text { vs. } 24.1 \% \text { at the end of treatment } \\
(p=0.06)\end{array}$ & $\begin{array}{c}46 \text { of } 67(68.7 \%) \text { patients } \\
\text { CFZ-containing short regimen vs. } \\
44 \text { of } 68(64.7 \%) \text { patients in long } \\
\text { regimen group }(p>0.05) \\
\text { Cured: } 42 \text { of } 67(62.7 \%) \text { vs. } 42 \text { of } 68 \\
\text { (61.8\%) patients } \\
\text { Treatment completion: } 4 \text { of } 67(6.0 \%) \\
\text { vs. } 2 \text { of } 68(2.9 \%) \text { patients }\end{array}$ \\
\hline
\end{tabular}


Table 1. Cont.

\begin{tabular}{|c|c|c|c|c|c|c|}
\hline \multirow{2}{*}{ Study } & \multirow{2}{*}{ Type of Study } & \multirow{2}{*}{ Dose and Duration of Clofazimine } & \multirow{2}{*}{$\begin{array}{l}\text { Other Drugs included } \\
\text { in the Regimen }\end{array}$} & \multicolumn{3}{|c|}{ Outcome } \\
\hline & & & & Time to Culture Conversion & Cavity Closure & Treatment Success Rate \\
\hline $\begin{array}{c}\text { Harouna, et al. [49] } \\
2019\end{array}$ & Observational-retrospective & $\begin{array}{l}\text { Dose: NA } \\
\text { Duration: } 9-14 \text { months }\end{array}$ & $\begin{array}{l}\text { KM, high-dose GTX, PTO, PZA, } \\
\text { medium-high-dose INH, EMB }\end{array}$ & $\begin{array}{l}\text { Start at } 1 \text { month after treatment } \\
\text { initiation (around } 30 \text { adults and } \\
5 \text { children/adolescents reached } \\
\text { negative smear-culture } \\
\text { conversion in month } 1 \text { ) }\end{array}$ & NA & $\begin{array}{l}9 \text { month regimen: } 88 \% \text { in adult and } \\
\text { 83\% in child/adolescent had } \\
\text { successful treatment } \\
12 \text { month regimen: } 90 \% \text { in adult and } \\
75 \% \text { in child/adolescent had } \\
\text { successful treatment }\end{array}$ \\
\hline \multicolumn{7}{|c|}{ XDR-TB } \\
\hline $\begin{array}{l}\text { Padayatchi, et al. [31] } \\
\qquad 2014\end{array}$ & Observational-retrospective & $\begin{array}{l}\text { Dose: } 200-300 \mathrm{mg} \text { (based on } \\
\text { weight), once daily } \\
\text { Duration: NA }\end{array}$ & $\begin{array}{c}\text { PZA, CM, ETO, MFX, PAS, } \\
\text { TRD, EMB, INH, AMX/CLV, } \\
\text { CLR, RIF, OFX }\end{array}$ & $\begin{array}{l}20 \text { of } 50(40 \%) \text { patients in the } \\
\text { CFZ-containing regimen group } \\
\text { vs. } 10 \text { of } 35 \text { ( } 28.6 \%) \text { patients in } \\
\text { the control group had culture } \\
\text { converted ( } p=0.05) \\
\text { Median time: } 16.4 \\
\text { vs. } 11.9 \text { weeks } \\
\text { After } 2 \text { months, the probability } \\
\text { of culture conversion was } \\
\text { higher in the CFZ-containing } \\
\text { regimen (around } 10 \text { vs. } 5 \%)\end{array}$ & $\begin{array}{l}\text { Change in CXR score by } 6 \text { months } \\
\text { was statistically significant }\end{array}$ & $\begin{array}{c}11 \text { of } 85(12.9 \%) \text { patients in all group } \\
\text { were cured or completed treatment } \\
37 \text { of } 85(43.5 \%) \text { patients in all group } \\
\text { died or were lost to follow-up (no } \\
\text { significant difference) }(p=0.493)\end{array}$ \\
\hline $\begin{array}{l}\text { Wang, et al. [51] } \\
2018 \\
\text { ChiCTR1800014800 }\end{array}$ & $\begin{array}{l}\text { Multicenter, prospective, and } \\
\text { randomized study }\end{array}$ & $\begin{array}{l}\text { Dose: } 100 \mathrm{mg} \text {, once daily } \\
\text { Duration: } 36 \text { months }\end{array}$ & $\begin{array}{l}\text { CM, MFX, GTX, PZA, EMB, } \\
\text { PAS, PTO, LFX, AMK, INH, } \\
\text { RIF, OFX }\end{array}$ & $\begin{array}{l}\text { Start at } 3 \text { months after } \\
\text { treatment initiation } \\
\text { Mean time: } \\
19.7 \text { vs. } 20.3 \text { months }\end{array}$ & NA & $\begin{array}{c}8 \text { of } 22(36.4 \%) \text { patients } \\
\text { CFZ-containing regimen vs. } 12 \text { of } 27 \\
\text { (44.4\%) patients in control group } \\
\text { had successful treatment } \\
\text { Cured: } 7 \text { of } 22(31.8 \%) \text { vs. } 6 \text { of } 27 \\
\text { (22.2\%) patients } \\
\text { Treatment completion: } 1 \text { of } 22(4.5 \%) \\
\text { vs. } 6 \text { of } 27(22.2 \%) \text { patients }\end{array}$ \\
\hline
\end{tabular}

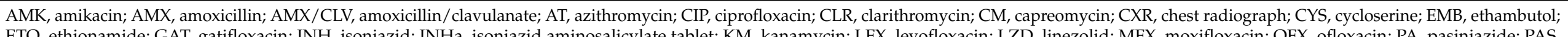

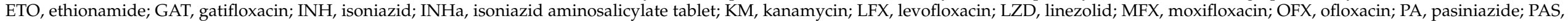
para-aminosalicylic acid; PTO, prothionamide; PZA, pyrazinamide; RE, rifapentine; RFB, rifabutin; RIF, rifampicin; SFX, sparfloxacin; STM, streptomycin; TRD, terizidone. 
In 2015, a multicenter, prospective, randomized, controlled, and open-label study assessed the efficacy of using clofazimine to treat MDR-TB in China, on 105 MDR-TB patients. Half of the patients $(n=53)$ were treated with the CCR, and 52 patients with a non-CCR. The results showed that regimens including clofazimine had a better effect; successful treatment rates in regimens, including and excluding clofazimine, were $73.6 \%$ vs. $53.8 \%(p=0.035)$. A proportion of patients had cavities, around $60 \%$ and $75 \%$ in patients with and without clofazimine, respectively, and cavity closure started at 3 months after treatment initiation. Thus, cavity closure occurred sooner in patients who received clofazimine compared with the control $(p=0.047)$. Time to culture conversion was also reported to start 3 months after treatment initiation, and earlier in the clofazimine group compared to the control $(p=0.042)$. Thus, cavity closure and time to culture conversion were reached earlier in patients who received a CCR [43].

In 2017, another cohort study in Brazil compared a CCR ( $n=1446$ patients) and pyrazinamide-containing regimen ( $n=1096$ patients) as a treatment for MDR-TB suggested that the successful treatment rate was similar between CCR and other regimens $(60.9 \%$ vs. $64.6 \%, p=0.054)$. Cure/treatment completion rates in the clofazimine or pyrazinamide regimen were $29.1 / 31.7 \%$ and $35 / 29.6 \%$. Hence, the CCR was effective and could potentially contribute to the successful treatment of MDR-TB [44].

Duan et al. [45] carried out a randomized and multicenter study on the addition of $100 \mathrm{mg}$ clofazimine into the standard regimen for MDR-TB. Their research indicated that the addition of clofazimine to the standard regimen exerted a better efficacy than that of the standard regimen. This efficacy was demonstrated by the successful treatment rate: $65.1 \%$ in the CCR compared with $47.3 \%$ in the standard regimen $(p=0.034)$. MDR-TB patients who received clofazimine reached culture conversion earlier than those in the control group $(p=0.0031)$.

A meta-analysis concluded that MDR-TB patients' treatment outcome was significantly better when using linezolid, a later generation of fluoroquinolone, bedaquiline, clofazimine and carbapenems, compared with standard treatment. The results showed that $61 \%$ had successful treatment, while $8 \%$ had failure or relapse, and $14 \%$ died. Treatment success was positively associated with the use of linezolid, levofloxacin, carbapenem, moxifloxacin, bedaquiline, and clofazimine. This study later became the cornerstone for the new MDR-TB regimen guideline [46].

In a prospective observational study, carried out in nine African countries on 1006 MDR-TB patients, treated with a standardized 9-month regimen that includes clofazimine, among untreated patients with SLDs, this regimen showed that $81.6 \%$ of patients were treated successfully. This study reported that the cure and treatment completion rates were $72.4 \%$ and $9.2 \%$, respectively. Thus, a shorter CCR demonstrated a favorable outcome and supported the use of a short regimen, as recommended by WHO [47].

Du et al. [48], in their multicenter, prospective, and randomized trial, compared shorter CCR and standard regimens to 135 MDR-TB patients. The sputum-culture conversion was achieved more rapidly in a shorter regimen containing the clofazimine group. The proportion of patients who reached sputum-culture conversion at the end of 3 months' treatment were $68.7 \%$ vs. $55.9 \%, p=0.04$, suggesting an early sputum conversion when using a shorter CCR. The cavity closure rate at the end of treatment in clofazimine-containing short regimen was similar to that of a standard regimen $(37.5 \%$ vs. $24.1 \%, p=0.06)$. Same for successful treatment rate $(68.7 \%$ vs. $64.7 \%, p>0.05)$. This study indicated that a shorter regimen containing clofazimine is superior in terms of anti-mycobacterial activity against MDR-TB when compared to the standard regimen.

An investigation in 2019, a prospective observational study, assessed the outcome in adults, children, and adolescents with MDR-TB in Nigeria. They were treated with a short regimen containing clofazimine and a 12-month regimen. The results showed that $88 \%$ of adults and $83 \%$ of children/adolescents in the 9 -month regimen, and $90 \%$ of adults and $75 \%$ of children/adolescents in the 12-month regimen, had successful treatment. This study also reported that around 30 adults and 5 children/adolescents reached negative smear-culture 
conversion within one month after treatment initiation. This study adds to the available evidence that short CCR is effective, whether in adults or children/adolescents [49].

When all studies are taken together, we can conclude that the CCR has better efficacy than regimens without clofazimine. This efficacy was shown by the better treatment outcomes, faster cavity closure and sputum-culture conversion, and decreased relapse rate. The short duration of CCR showed a comparably successful outcome, supporting the use of the WHO's short regimen. Clofazimine was an effective antibiotic used to treat MDR-TB, and associated with successful treatment [12,33,41-49].

\subsection{Effectivity of Clofazimine for Treating XDR-TB}

Extensively drug-resistant tuberculosis (XDR-TB) refers to MDR-TB, which is also resistant to fluoroquinolone and second-line injectable anti-TB drugs (kanamycin, capreomycin, or amikacin), and is more severe than pre-XDR-TB. Pre-XDR-TB refers to MDR-TB that is also resistant to either fluoroquinolone or second-line injectable anti-TB drugs, but not both [1]. Some studies into clofazimine for XDR-TB showed a contrary result [31,51].

A retrospective cohort study in South Africa on XDR-TB patients was performed in 2014. Fifty patients were treated with CCR, and 35 patients with a non-CCR. Clofazimine was associated with improved culture conversion and changes in CXR score. CCR had a higher rate of culture conversion $(40 \%)$, with a 2 -fold increase at 6 months, compared with $28.6 \%$ in the control group $(p=0.05)$. Besides this, there were changes in the chest radiograph (CXR) score by 6 months from baseline, which were statistically significant [31]. In another multicenter, prospective, and randomized study in China on the efficacy of clofazimine when added to the recommended regimen, it was found that the successful treatment rate showed no significant difference in the CCR compared to that in the standard regimen $(36.4 \%$ vs. $44.4 \%, p=0.493)$. The mean sputum culture conversion time is shorter in the CCR than in the control group, but this difference was not statistically significant, probably due to the small sample size. This study shows that the CCR has a limited benefit when used as the treatment for XDR-TB [51].

The results of the two studies are contradictory. The investigation into CCR for XDRTB needs to be deepened. From the evidence available to date, we can conclude that the CCR has better efficacy than the non-CCR in MDR-TB, but this is not yet confirmed for XDR-TB [31,51].

\subsection{Safety and Tolerability of Clofazimine}

In general, clofazimine was described as a safe and well-tolerated drug combined with other regimens of MDR-TB, and showed a low incidence of serious adverse events (SAEs) [43]. Anderson et al. [52] conducted an in vitro study using human platelets, which showed some negative effects of clofazimine. Clofazimine was identified to have a potentially adverse pro-thrombotic activity. This pro-thrombotic activity may predispose patients with MDR/XDR-TB for the development of cardiac dysfunction.

Grosset et al. [34] conducted a study on the addition of clofazimine to the standard second-line regimen for TB in mice model of MDR-TB. They added clofazimine to the regimen, which resulted in a brownish discoloration of the internal tissues, tail, and ears of mice. A systematic review revealed that this adverse effect of clofazimine is minor and rarely life-threatening [53]. The most common adverse effect of clofazimine is pigmentation or discoloration of skin because of clofazimine's deposition in tissue. Other studies found that the addition of clofazimine to the standard routine regimen of MDR-TB came with high incidences of hepatic dysfunction, which are significant adverse events for patients receiving complicated regimens containing clofazimine $[45,51]$.

Surveillance of adverse events in the treatment of DR-TB showed that QT prolongation and arrhythmias were common in patients who take para-aminosalicylic acid, bedaquiline, moxifloxacin, clofazimine, and delamanid [54]. However, in a small cohort, clofazimine did not cause significant QT prolongation. This QT prolongation may be caused by concomitant 
medication or other MDR-TB regimen drugs [55]. Sometimes, diarrhea and clostridium difficile enterocolitis occurred, but all anti-TB drugs could be induced [54].

Based on the MDR-TB guideline in 2019, clofazimine belongs to the drugs in the MDR-TB regimen which are associated with a low incidence of severe AEs (SAEs). This guideline mentioned that the absolute risk of SAEs of clofazimine is around $3.6 \%$ in patients on a longer MDR-TB regimen, lower than that of other drugs, e.g., for linezolid (17.2\%) [2]. A meta-analysis by Lan et al. [56] reported that clofazimine's adverse events, leading to permanent discontinuation of the drug, only appeared in 12 of 1712 patients using the medicine. Clofazimine had the lowest incidence of adverse events leading to permanent drug discontinuation compared with other anti-TB drugs, followed by fluoroquinolones and bedaquiline. According to this study, the adverse events of clofazimine often appear as cardiovascular $(4.33 \%)$, hyperpigmentation $(5.42 \%)$, rash $(2.17 \%)$, and gastrointestinal $(1.8 \%)$. Hyperpigmentation is essential for the patient, but it did not seem to be a common cause of permanent drug discontinuation.

Furthermore, we can conclude that clofazimine's adverse effects are rarely life-threatening and usually minor [53]. Skin discoloration is the most common adverse effect [45,51]. Other minor adverse effects are rash and other skin allergies [56]. The major adverse effects that can arise with the use of a CCR are hepatic dysfunction, QT prolongation, arrhythmias, diarrhea, enterocolitis, and pro-thrombotic activity. Thus, the use of clofazimine still needs to be monitored $[52,56]$.

\subsection{Mechanisms of Resistance to Clofazimine}

The mechanisms of resistance to clofazimine are due mainly to mutations in the rv0678 gene, with concomitant upregulation of the efflux pump, MmpL5, and occasionally in ro1979c or rv2535c (pepQ) gene [57,58]. Mutations in the rv0678 gene are a major mechanism of resistance to clofazimine [57]. Ninety-seven percent (93/96) of clofazimine-resistant mutants had a mutation in the $r 00678$ gene which encodes a transcriptional repressor for the efflux pump MmpL5 [57-59]. The Rv0678 protein is the transcriptional regulator which represses the expression of mmpS5 and mmpL5 genes. The mmpS5 and mmpL5 is the gene that encodes multi-substrate MmpS5 and MmpL5 efflux pumps $[58,60]$.

Mutation in the ro0678 gene also leads to cross-resistance to bedaquiline in Mycobacterium tuberculosis isolates [8]. An in vitro study conducted by Hartkoorn et al. [58] confirmed the role of the rv0678 gene in resisting clofazimine and bedaquiline. This gene was expressed from the $h s p 60$ promoter in the integrative vector pMV261 in M. tuberculosis strain H37Rv. Resazurin Reduction Microplate Assay (REMA) was used to evaluate drug susceptibility and showed that the expression of Rv0678 in H37Rv leads to partial resistance to clofazimine and bedaquiline. Another study by Andries et al. [61] reported that mutations in the rv0678 gene in preclinical isolates are associated with the higher MIC of bedaquiline (8-fold), as high as the MIC increases for clofazimine. Besides this, the increase in MIC ranged from 2-fold to 16-fold, depending on the mutation in the clinical isolates. The mutation in the ro0678 gene caused the MIC increases for bedaquiline, and clofazimine were, again, very similar to these isolates. A new study in 2020 strengthens this evidence and is especially emergent in southern Africa. A new design for an intense regimen that includes highly effective agents, e.g., linezolid, may overcome this resistance, yet needs to be evaluated further. Additionally, drug susceptibility testing is required to identify drug resistance and design a customized drug regimen for MDR-TB [62].

Zhang et al. [57] also discovered two new genes ( $r v 1979 \mathrm{c}$ and $r v 2535 c)$ associated with clofazimine resistance in mutants without $r v 0678$ mutation, although the role of $r v 1979 \mathrm{c}$ and $r v 2535 \mathrm{c}$ in clofazimine resistance still needs to be investigated. The molecular function of Rv1979c protein is suggested to be that of amino acid transporters with permease activity, yet the molecular process of Rv2535c has not been fully identified; it is likely to be that of a peptidase [63]. In their study, Almeida et al. [59] demonstrated that the loss-offunction mutation in $p e p Q$ ( $r v 2535 c$ gene) confers decreased susceptibility to clofazimine both in vitro and in mice, but the mechanism by which it does so is still unclear. This 
study suggested that the mutation in $p e p Q$ is not associated with overexpression of mmpL5 or mmpS5. This mutation may increase efflux through this transporter by a different means, such as preventing degradation of MmpL5. Another study demonstrated that this $p e p Q$ gene also has a role in cross-resistance between clofazimine and bedaquiline. Mutations in $p e p Q$ were linked with low-level resistance to bedaquiline and cross-resistance to clofazimine. This mutation also decreased both drugs' efficacy in vivo but did not lead to complete resistance to these drugs and an increase in bedaquiline and clofazimine MICs, 4-fold [64].

The contributions of efflux pumps to clofazimine resistance in $M$. tuberculosis generated some studies regarding the use of the efflux pump inhibitor to overcome this drug resistance and ensure the effectiveness of this drug. Although some efflux inhibitors have been investigated, most of them have only been studied in vitro and ex vivo; some moved to in vivo studies and raised concerns about toxicity. Some drugs have been studied in vitro, such as verapamil, reserpine and piperine $[65,66]$. Verapamil was shown to decrease the MIC of bedaquiline and clofazimine to $M$. tuberculosis by 8 - and 16-fold. These findings need to be further investigated to identify verapamil and clofazimine's synergistic effects in an animal model [67]. Another study showed that the use of verapamil and reserpine decreased the MICs of both bedaquiline and clofazimine, yet these results were reduced in mutants with higher baseline MICs in preclinical isolates. In clinical isolates, reserpine at $3 \mu \mathrm{g} / \mathrm{mL}$ decreased the MICs of bedaquiline and clofazimine, but the efflux pump was less susceptible to reserpine when the MICs were high, resulting in smaller MIC reductions. The use of reserpine greater than $3 \mu \mathrm{g} / \mathrm{mL}$ detained the growth of some clinical isolates. Verapamil also decreased the MICs of both bedaquiline and clofazimine in clinical isolates. Efflux pump inhibitors for clofazimine resistance still need to be evaluated, especially in a clinical setting [61].

\section{Future of Clofazimine for Treating Multidrug-Resistant Tuberculosis}

As discussed in the previous sections, CCR showed better efficacy than the standard regimen, and the addition of clofazimine to the regimen can shorten the length of treatment duration. The adverse effects of clofazimine are typically relatively mild, such as skin discoloration due to the drugs' deposition. With this evidence, we might consider using an optimal or higher dose of clofazimine for better efficacy or to shorten the treatment duration. The optimal or higher dose of clofazimine for treating MDR-TB still needs further investigation, especially in a clinical setting.

Lu et al. [68], in their in vitro study with 12 clofazimine analogs, showed that 9 of the 12 analogs have lower lipophilicity and a shorter half-life plasma concentration compared to clofazimine. This evidence indicated that these analogs had a lower possibility of accumulating or precipitating in tissues. The rate of skin discoloration could be reduced with these analogs. They still need to be investigated further in in vivo and clinical studies.

A new formulation of clofazimine was made by Murashov et al. [69]. The new formulation type is a biocompatible, biomimetic formulation of clofazimine- $\mathrm{HCl}$ microcrystals. This formulation proved to be appropriate for parenteral or systemic administration. This type could avoid skin pigmentation or discoloration and immunological responses from oral clofazimine administration. This study suggested that an overt toxicological effect cannot explain a lack of skin pigmentation in the clofazimine- $\mathrm{HCl}$ injected mice. Based on these data, the new formulation can be used as an alternative to oral clofazimine administration to avoid skin discoloration and immunological response, yet needs to be evaluated further in the clinical setting.

\section{Conclusions}

The increasing incidence of MDR-TB, followed by the low success rate of treatments worldwide, raise the need for a more viable treatment. The current evidence recommends a clofazimine-containing regimen. Clofazimine-containing regimens show better efficacy compared to the standard regimen. The use of clofazimine can possibly shorten the length 
of MDR-TB treatment with typically minor adverse effects, with serious adverse effects being rare. However, the optimal dose and duration of treatment with clofazimine need further investigation.

Author Contributions: Prepare an outline, R.V.N.; writing-original draft preparation, R.V.N.; writing-review and editing, R.V.N., V.Y., P.S., R.E.A. and R.R.; supervision, V.Y., R.E.A. and R.R. All authors have read and agreed to the published version of the manuscript.

Funding: This research and APC was funded by the Directorate of Research and Community Service, Deputy for Strengthening Research and Development, Ministry of Research, Technology/National Research and Innovation Agency of the Republic of Indonesia in the PMDSU Scholarship Program with contract number 1827/UN.6.3.1/LT/2020. R.R received ALG (Academic Leadership Program), an internal Universitas Padjadjaran research funding with contract number 3855/UN.C/LT/2019.

Acknowledgments: We acknowledge the Directorate of Research and Community Service, Deputy for Strengthening Research and Development, Ministry of Research, Technology/National Research and Innovation Agency of the Republic of Indonesia in the PMDSU Scholarship Program.

Conflicts of Interest: The authors declare no conflict of interest.

\section{References}

1. Brown, E.G.; Dooley, D.S.; Smith, K. Drug-Resistant Tuberculosis: A Survival Guide for Clinicians, 3rd ed.; Curry International Tuberculosis Center: Berkeley, CA, USA, 2016.

2. World Health Organization. What is New in the WHO Consolidated Guidelines on Drug-Resistant Tuberculosis Treatment? WHO: Geneva, Switzerland, 2019; ISBN 9789241550529.

3. Centers for Disease Control and Prevention (CDC). Core Curriculum on Tuberculosis: What the Clinician Should Know, 6th ed.; CDC: Atlanta, GA, USA, 2013.

4. World Health Organization. Global Tuberculosis Report 2020; WHO: Geneva, Switzerland, 2020; ISBN 9789240013131.

5. Cholo, M.C.; Steel, H.C.; Fourie, P.B.; Germishuizen, W.A.; Anderson, R. Clofazimine: Current status and future prospects. J. Antimicrob. Chemother. 2012, 67, 290-298. [CrossRef] [PubMed]

6. $\quad$ Lange, C.; Dheda, K.; Chesov, D.; Mandalakas, A.M.; Udwadia, Z.; Horsburgh, C.R. Management of drug-resistant tuberculosis. Lancet 2019, 394, 953-966. [CrossRef]

7. Barry, V.C.; Belton, J.G.; Conalty, M.L. A New Series of Phenazine (Rimino-Compounds) with High Antituberculosis Activity. Nature 1957, 179, 1013-1015. [CrossRef] [PubMed]

8. Cholo, M.C.; Mothiba, M.T.; Fourie, B.; Anderson, R. Mechanisms of action and therapeutic efficacies of the lipophilic antimycobacterial agents clofazimine and bedaquiline. J. Antimicrob. Chemother. 2017, 72, 338-353. [CrossRef] [PubMed]

9. Vischer, W.A. The experimental properties of G 30320 (B 663)-A new anti-leprotic agent. Lepr. Rev. 1969, 40, 107-110. [CrossRef] [PubMed]

10. Redd, V.M.; O'Sullivan, J.F.; Gangadharam, P.R.J. Antimycobacterial activities of riminophenazines. J. Antimicrob. Chemother. 1999, 43, 615-623. [CrossRef] [PubMed]

11. Schaad-Lanyi, Z.; Dieterle, W.; Dubois, J.P.; Theobald, W.; Vischer, W. Pharmacokinetics of clofazimine in healthy volunteers. Int. J. Lepr. 1987, 55, 9-15.

12. Van Deun, A.; Maug, A.K.J.; Salim, M.A.H.; Das, P.K.; Sarker, M.R.; Daru, P.; Rieder, H.L. Short, highly effective, and inexpensive standardized treatment of multidrug-resistant tuberculosis. Am. J. Respir. Crit. Care Med. 2010, 182, 684-692. [CrossRef]

13. Lange, C.; Chesov, D.; Heyckendorf, J. Clofazimine for the treatment of multidrug-resistant tuberculosis. Clin. Microbiol. Infect. 2019, 25, 128-130. [CrossRef]

14. World Health Organization. WHO Consolidated Guidelines on Tuberculosis; WHO: Geneva, Switzerland, 2020; ISBN 9789240007048.

15. Mirnejad, R.; Asadi, A.; Khoshnood, S.; Mirzaei, H.; Heidary, M.; Fattorini, L.; Ghodousi, A.; Darban-Sarokhalil, D. Clofazimine: A useful antibiotic for drug-resistant tuberculosis. Biomed. Pharmacother. 2018, 105, 1353-1359. [CrossRef]

16. NCBI Clofazimine. Available online: https:// pubchem.ncbi.nlm.nih.gov/compound/Clofazimine (accessed on 15 December 2020).

17. Bopape, M.C.; Steel, H.C.; Cockeran, R.; Matlola, N.M.; Fourie, P.B.; Anderson, R. Antimicrobial activity of clofazimine is not dependent on mycobacterial C-type phospholipases. J. Antimicrob. Chemother. 2004, 53, 971-974. [CrossRef]

18. Fukutomi, Y.; Maeda, Y.; Makino, M. Apoptosis-inducing activity of clofazimine in macrophages. Antimicrob. Agents Chemother. 2011, 55, 4000-4005. [CrossRef]

19. Lechartier, B.; Cole, S.T. Mode of Action of Clofazimine and Combination Therapy with Benzothiazinones against Mycobacterium tuberculosis. Antimicrob. Agents Chemother. 2015, 59, 4457-4463. [CrossRef]

20. Diacon, A.H.; Dawson, R.; Von Groote-Bidlingmaier, F.; Symons, G.; Venter, A.; Donald, P.R.; van Niekerk, C.; Everitt, D.; Hutchings, J.; Burger, D.A.; et al. Bactericidal activity of pyrazinamide and clofazimine alone and in combinations with pretomanid and bedaquiline. Am. J. Respir. Crit. Care Med. 2015, 191, 943-953. [CrossRef] 
21. Ammerman, N.C.; Swanson, R.V.; Tapley, A.; Moodley, C.; Ngcobo, B.; Adamson, J.; Dorasamy, A.; Moodley, S.; Mgaga, Z.; Bester, L.A.; et al. Clofazimine has delayed antimicrobial activity against Mycobacterium tuberculosis both in vitro and in vivo. J. Antimicrob. Chemother. 2017, 72, 455-461. [CrossRef]

22. Li, G.; Xu, Z.; Jiang, Y.; Liu, H.; Zhao, L.-1.; Li, M.; Xu, D.; Zhao, X.; Liu, Z.; Wang, R.; et al. Synergistic activities of clofazimine with moxifloxacin or capreomycin against Mycobacterium tuberculosis in China. Int. J. Antimicrob. Agents 2019, 54, 642-646. [CrossRef]

23. López-Gavín, A.; Tudó, G.; Vergara, A.; Hurtado, J.C.; Gonzalez-Martín, J. In vitro activity against Mycobacterium tuberculosis of levofloxacin, moxifloxacin and UB-8902 in combination with clofazimine and pretomanid. Int. J. Antimicrob. Agents 2015, 46, 582-585. [CrossRef]

24. Maartens, G.; Brill, M.J.E.; Pandie, M.; Svensson, E.M. Pharmacokinetic interaction between bedaquiline and clofazimine in patients with drug-resistant tuberculosis. Int. J. Tuberc. Lung Dis. 2018, 22, 26-29. [CrossRef]

25. Holdiness, M.R. Clinical Pharmacokinetics of Clofazimine: A Review. Clin. Pharmacokinet. 1989, 85, 74-85. [CrossRef]

26. Nix, D.E.; Adam, R.D.; Auclair, B.; Krueger, T.S.; Godo, P.G.; Peloquin, C.A. Pharmacokinetics and relative bioavailability of clofazimine in relation to food, orange juice and antacid. Tuberculosis 2004, 365-373. [CrossRef]

27. Baik, J.; Stringer, K.A.; Mane, G.; Rosania, G.R. Multiscale distribution and bioaccumulation analysis of clofazimine reveals a massive immune system-mediated xenobiotic sequestration response. Antimicrob. Agents Chemother. 2013, 57, 1218-1230. [CrossRef]

28. Silva Miranda, M.; Breiman, A.; Allain, S.; Deknuydt, F.; Altare, F. The tuberculous granuloma: An unsuccessful host defence mechanism providing a safety shelter for the bacteria? Clin. Dev. Immunol. 2012, 2012. [CrossRef]

29. Prideaux, B.; Via, L.E.; Zimmerman, M.D.; Eum, S.; Sarathy, J.; O’brien, P.; Chen, C.; Kaya, F.; Weiner, D.M.; Chen, P.; et al. The association between sterilizing activity and drug distribution into tuberculosis lesions. Nat. Med. 2015, 21, 1223-1227. [CrossRef]

30. Te Brake, L.H.M.; Russel, F.G.M.; Van Den Heuvel, J.J.M.W.; De Knegt, G.J.; De Steenwinkel, J.E.; Burger, D.M.; Aarnoutse, R.E.; Koenderink, J.B. Inhibitory potential of tuberculosis drugs on ATP-binding cassette drug transporters. Tuberculosis 2016, 96, 150-157. [CrossRef]

31. Padayatchi, N.; Gopal, M.; Naidoo, R.; Werner, L.; Naidoo, K.; Master, I.; O’Donnell, M.R.; Donnell, M.R.O. Clofazimine in the treatment of extensively drug-resistant tuberculosis with HIV coinfection in South Africa: A retrospective cohort study. J. Antimicrob. Chemother. 2014, 69, 3103-3107. [CrossRef]

32. Mitnick, C.D.; Shin, S.S.; Seung, K.J.; Rich, M.L.; Atwood, S.S.; Furin, J.J.; Fitzmaurice, G.M.; Alcantara Viru, F.A.; Appleton, S.C.; Bayona, J.N.; et al. Comprehensive Treatment of Extensively Drug-Resistant Tuberculosis. N. Engl. J. Med. 2008, 359, 563-574 [CrossRef]

33. Dey, T.; Brigden, G.; Cox, H.; Shubber, Z.; Cooke, G.; Ford, N. Outcomes of clofazimine for the treatment of drug-resistant tuberculosis: A systematic review and meta-analysis. J. Antimicrob. Chemother. 2013, 68, 284-293. [CrossRef]

34. Grosset, J.H.; Tyagi, S.; Almeida, D.V.; Converse, P.J.; Li, S.Y.; Ammerman, N.C.; Bishai, W.R.; Enarson, D.; Trébucq, A. Assessment of clofazimine activity in a second-line regimen for tuberculosis in mice. Am. J. Respir. Crit. Care Med. 2013, 188, 608-612. [CrossRef]

35. Ammerman, N.C.; Swanson, R.V.; Bautista, E.M.; Almeida, D.V.; Saini, V.; Omansen, T.F.; Guo, H.; Chang, Y.S.; Li, S.-Y.Y.; Tapley, A.; et al. Impact of clofazimine dosing on treatment shortening of the first-line regimen in a mouse model of tuberculosis. Antimicrob. Agents Chemother. 2018, 62, 1-18. [CrossRef]

36. Gautam, U.S.; McGillivray, A.; Mehra, S.; Didier, P.J.; Midkiff, C.C.; Kissee, R.S.; Golden, N.A.; Alvarez, X.; Niu, T.; Rengarajan, J.; et al. DosS is required for the complete virulence of mycobacterium tuberculosis in mice with classical granulomatous lesions. Am. J. Respir. Cell Mol. Biol. 2015, 52, 708-716. [CrossRef]

37. Irwin, S.M.; Gruppo, V.; Brooks, E.; Gilliland, J.; Scherman, M.; Reichlen, M.J.; Leistikow, R.; Kramnik, I.; Nuermberger, E.L.; Voskuil, M.I.; et al. Limited activity of clofazimine as a single drug in a mouse model of tuberculosis exhibiting caseous necrotic granulomas. Antimicrob. Agents Chemother. 2014, 58, 4026-4034. [CrossRef] [PubMed]

38. Harper, J.; Skerry, C.; Davis, S.L.; Tasneen, R.; Weir, M.; Kramnik, I.; Bishai, W.R.; Pomper, M.G.; Nuermberger, E.L.; Jain, S.K. Mouse model of necrotic tuberculosis granulomas develops hypoxic lesions. J. Infect. Dis. 2012, 205, 595-602. [CrossRef] [PubMed]

39. Gautam, U.S.; Mehra, S.; Kaushal, D. In-vivo gene signatures of Mycobacterium tuberculosis in C3HeB/FeJ mice. PLoS ONE 2015, 10, 1-25. [CrossRef] [PubMed]

40. Driver, E.R.; Ryan, G.J.; Hoff, D.R.; Irwin, S.M.; Basaraba, R.J.; Kramnik, I.; Lenaerts, A.J. Evaluation of a mouse model of necrotic granuloma formation using $\mathrm{C} 3 \mathrm{HeB} / \mathrm{FeJ}$ mice for testing of drugs against Mycobacterium tuberculosis. Antimicrob. Agents Chemother. 2012, 56, 3181-3195. [CrossRef] [PubMed]

41. Xu, H.-B.B.; Jiang, R.-H.H.; Xiao, H.-P.P. Clofazimine in the treatment of multidrug-resistant tuberculosis. Clin. Microbiol. Infect. 2012, 18, 1104-1110. [CrossRef] [PubMed]

42. Aung, K.J.M.M.; Van Deun, A.; Declercq, E.; Sarker, M.R.; Das, P.K.; Hossain, M.A.; Rieder, H.L. Successful “9-month Bangladesh regimen" for multidrugresistant tuberculosis among over 500 consecutive patients. Int. J. Tuberc. Lung Dis. 2014, 18, 1180-1187. [CrossRef] [PubMed] 
43. Tang, S.; Yao, L.; Hao, X.; Liu, Y.; Zeng, L.; Liu, G.; Li, M.; Li, F.; Wu, M.; Zhu, Y.; et al. Clofazimine for the treatment of multidrug-resistant tuberculosis: Prospective, multicenter, randomized controlled study in China. Clin. Infect. Dis. 2015, 60, 1361-1367. [CrossRef]

44. Dalcolmo, M.; Gayoso, R.; Sotgiu, G.; D'Ambrosio, L.; Rocha, J.L.; Borga, L.; Fandinho, F.; Braga, J.U.; Galesi, V.M.N.N.; Barreira, D.; et al. Effectiveness and safety of clofazimine in multidrug-resistant tuberculosis: A nationwide report from Brazil. Eur. Respir. J. 2017, 49, 9-13. [CrossRef]

45. Duan, H.; Chen, X.; Li, Z.; Pang, Y.; Jing, W.; Liu, P.; Wu, T.; Cai, C.; Shi, J.; Qin, Z.; et al. Clofazimine improves clinical outcomes in multidrug-resistant tuberculosis: A randomized controlled trial. Clin. Microbiol. Infect. 2019, 25, 190-195. [CrossRef]

46. Ahmad, N.; Ahuja, S.D.; Akkerman, O.W.; Alffenaar, J.-W.C.; Anderson, L.F.; Baghaei, P.; Bang, D.; Barry, P.M.; Bastos, M.L.; Behera, D.; et al. Treatment correlates of successful outcomes in pulmonary multidrug-resistant tuberculosis: An individual patient data meta- analysis. Lancet 2018, 392, 821-834. [CrossRef]

47. Trebucq, A.; Schwoebel, V.; Kashongwe, Z.; Bakayoko, A.; Kuaban, C.; Noeske, J.; Hassane, S.; Souleymane, B.; Piubello, A.; Ciza, F.; et al. Treatment outcome with a short multidrug-resistant tuberculosis regimen in nine African countries. Int. J. Tuberc. Lung Dis. 2018, 22, 17-25. [CrossRef]

48. Du, Y.; Qiu, C.; Chen, X.; Wang, J.J.; Jing, W.; Pan, H.; Chen, W.; Liu, Y.; Li, C.; Xi, X.; et al. Treatment outcome of a shorter regimen containing clofazimine for multidrug-resistant tuberculosis: A randomized control trial in China. Clin. Infect. Dis. 2019, 1-8. [CrossRef]

49. Harouna, S.H.; Souleymane, M.B.; Kizito, W.; Morou, S.; Boukary, I. Short-course treatment outcomes and adverse events in adults and children-adolescents with MDR-TB in Niger. Int. J. Tuberc. Lung Dis. 2019, 23, 625-630. [CrossRef]

50. Laserson, K.F.; Thorpe, L.E.; Leimane, V.; Weyer, K.; Mitnick, C.D.; Riekstina, V.; Zarovska, E.; Rich, M.L.; Fraser, H.S.F.; Alarcón, E.; et al. Speaking the same language: Treatment outcome definitions for multidrug-resistant tuberculosis. Int. J. Tuberc. Lung Dis. 2005, 9, 640-645.

51. Wang, Q.; Pang, Y.; Jing, W.; Liu, Y.; Wang, N.; Yin, H.; Zhang, Q.; Ye, Z.; Zhu, M.; Li, F.; et al. Clofazimine for treatment of extensively drug-resistant pulmonary tuberculosis in China. Antimicrob. Agents Chemother. 2018, 62, 1-9. [CrossRef]

52. Anderson, R.; Theron, A.J.; Nel, J.G.; Durandt, C.; Cholo, M.C.; Feldman, C.; Tintinger, G.R. Clofazimine, but not isoniazid or rifampicin, augments platelet activation in vitro. Front. Pharmacol. 2018, 9, 1-5. [CrossRef]

53. Gopal, M.; Padayatchi, N.; Metcalfe, J.Z.; O'Donnell, M.R.; Donnell, M.R.O. Systematic review of clofazimine for the treatment of drug-resistant tuberculosis. Int. J. Tuberc. Lung Dis. 2013, 17, 1001-1007. [CrossRef]

54. Borisov, S.; Danila, E.; Maryandyshev, A.; Dalcolmo, M.; Miliauskas, S.; Kuksa, L.; Manga, S.; Skrahina, A.; Diktanas, S.; Codecasa, L.R.; et al. Surveillance of adverse events in the treatment of drug-resistant tuberculosis: First global report. Eur. Respir. J. 2019, 54, 1901522. [CrossRef]

55. Zweijpfenning, S.M.H.; Van Groningen, H.; Van Ingen, J.; Magis-Escurra, C.; Boeree, M.J.; Wagner, D.; Bax, H.; Andrejak, C.; Wener, R.; Rahman, A.; et al. Clofazimine does not lead to significant QT interval prolongation: A multicentre study. Eur. Respir. J. 2018, 52, 8-10. [CrossRef]

56. Lan, Z.; Ahmad, N.; Baghaei, P.; Barkane, L.; Benedetti, A.; Brode, S.K.; Brust, J.C.M.; Campbell, J.R.; Chang, V.W.L.; Falzon, D.; et al. Drug-associated adverse events in the treatment of multidrug-resistant tuberculosis: An individual patient data meta-analysis. Lancet Respir. Med. 2020, 8, 383-394. [CrossRef]

57. Zhang, S.; Chen, J.; Cui, P.; Shi, W.; Zhang, W.; Zhang, Y. Identification of novel mutations associated with clofazimine resistance in Mycobacterium tuberculosis. J. Antimicrob. Chemother. 2015, 70, 2507-2510. [CrossRef] [PubMed]

58. Hartkoorn, R.C.; Uplekar, S.; Cole, S.T. Cross-resistance between clofazimine and bedaquiline through upregulation of mmpl5 in mycobacterium tuberculosis. Antimicrob. Agents Chemother. 2014, 58, 2979-2981. [CrossRef] [PubMed]

59. Somoskovi, A.; Bruderer, V.; Homke, R.; Bloemberg, G.V.; Bottger, E.C. A mutation associated with clofazimine and bedaquiline cross-resistance in MDR-TB following bedaquiline treatment. Eur. Respir. J. 2015, 45, 554-557. [CrossRef] [PubMed]

60. Pym, A.S.; Diacon, A.H.; Tang, S.J.; Conradie, F.; Danilovits, M.; Chuchottaworn, C.; Vasilyeva, I.; Andries, K.; Bakare, N.; De Marez, T.; et al. Bedaquiline in the treatment of multidrug- and extensively drugresistant tuberculosis. Eur. Respir. J. 2016, 47, 564-574. [CrossRef]

61. Andries, K.; Villellas, C.; Coeck, N.; Thys, K.; Gevers, T.; Vranckx, L.; Lounis, N.; de Jong, B.C.; Koul, A. Acquired Resistance of Mycobacterium tuberculosis to Bedaquiline. PLOS ONE 2014, 9. [CrossRef]

62. Nimmo, C.; Millard, J.; van Dorp, L.; Brien, K.; Moodley, S.; Wolf, A.; Grant, A.D.; Padayatchi, N.; Pym, A.S.; Balloux, F.; et al. Population-level emergence of bedaquiline and clofazimine resistance-associated variants among patients with drug-resistant tuberculosis in southern Africa: A phenotypic and phylogenetic analysis. Lancet Microbe 2020, 1, e165-e174. [CrossRef]

63. Hamidian, M.; Hall, R.M. Origin of the AbGRI1 antibiotic resistance island found in the comM gene of Acinetobacter baumannii GC2 isolates. J. Antimicrob. Chemother. 2017, 72, 2944-2947. [CrossRef]

64. Nguyen, T.V.A.; Anthony, R.M.; Bañuls, A.L.; Vu, D.H.; Alffenaar, J.W.C. Bedaquiline Resistance: Its Emergence, Mechanism, and Prevention. Clin. Infect. Dis. 2018, 66, 1625-1630. [CrossRef]

65. Anthony Malinga, L.; Stoltz, A. Efflux Pump Mediated Second-Line Tuberculosis Drug Resistance. Mycobact. Dis. 2016, 6. [CrossRef]

66. Rodrigues, L.; Cravo, P.; Viveiros, M. Efflux pump inhibitors as a promising adjunct therapy against drug resistant tuberculosis: A new strategy to revisit mycobacterial targets and repurpose old drugs. Expert Rev. Anti. Infect. Ther. 2020, 18, 741-757. [CrossRef] 
67. Gupta, S.; Cohen, K.A.; Winglee, K.; Maiga, M.; Diarra, B.; Bishai, W.R. Efflux inhibition with verapamil potentiates bedaquiline in mycobacterium tuberculosis. Antimicrob. Agents Chemother. 2014, 58, 574-576. [CrossRef]

68. Lu, Y.; Zheng, M.; Wang, B.; Fu, L.; Zhao, W.; Li, P.; Xu, J.; Zhu, H.; Jin, H.; Yin, D.; et al. Clofazimine analogs with efficacy against experimental tuberculosis and reduced potential for accumulation. Antimicrob. Agents Chemother. 2011, 55, 5185-5193. [CrossRef]

69. Murashov, M.D.; Diaz-Espinosa, J.; Lalone, V.; Tan, J.W.Y.Y.; Laza, R.; Wang, X.; Stringer, K.A.; Rosania, G.R. Synthesis and characterization of a biomimetic formulation of clofazimine hydrochloride microcrystals for parenteral administration. Pharmaceutics 2018, 10, 238. [CrossRef] 